\title{
TANTANGAN GEREJA DALAM MENGATASI KENAKALAN REMAJA KRISTEN DI GABK BUKIT MORIA MANGAIS
}

\author{
Pira Satria Sitoki, Junni Yokiman, Nanchy Lepong Bulan \\ Sekolah Tinggi Teologi Star's Lub Luwuk Banggai
}

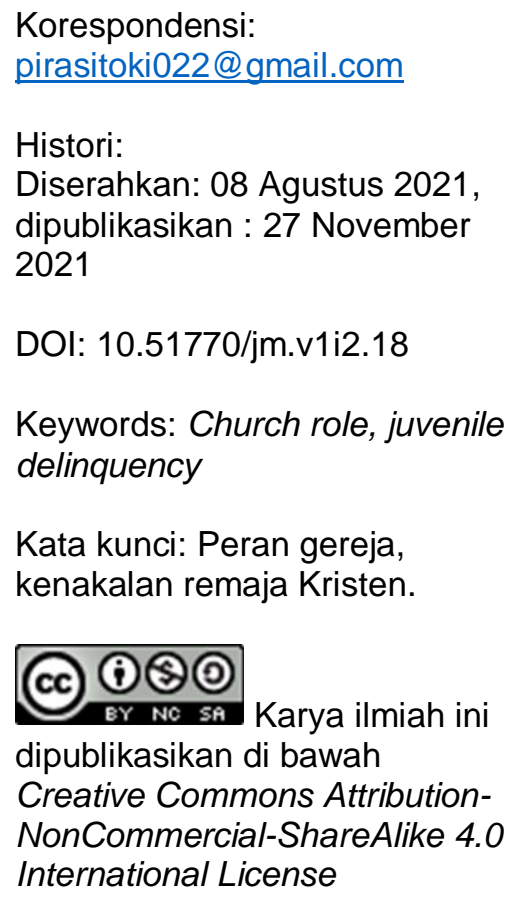

Tujuan penelitian ini antara lain: untuk mengetahui apa tantangan Gereja dalam mengatasi kenakalan remaja kristen di GABK Bukit Moria Mangais. Dalam penelitian ini, penulis mengkaji masalah menggunakan metode kualitatif dengan menggunakan pendekatan studi kasus untuk penjelajahan lapangan dengan tujuan memperoleh pengetahuan yang lebih banyak dalam suatu keadaan atau suatu kasus. Penulis menggunakan beberapa sumber seperti: buku-buku, jurnal dan media yang lain sebagai sumber informasi. Adapun hasil dari penelitian, penulis mendapati bahwa Gereja belum sepenuhnya berperan dan bertanggung jawab dengan baik dalam menghadapi tantangan kenakalan remaja kristen yang terjadi di Gereja. Hal ini memberikan dampak yang negatif bagi perkembangan remaja di masa mudanya. Untuk itu gereja harus berperan aktif dalam mengatasi kenakalan remaja kristen. Dengan demikian penulis melihat topik mengenai tantangan Gereja dalam mengatasi kenakalan remaja kristen masih sangat relevan untuk diteliti dan dimuat dalam sebuah karya tulis. 


\section{PENDAHULUAN}

Masa remaja merupakan masa perkembangan dan peralihan. Pada masa ini remaja berada dalam proses berkembang ke arah kematangan dan kemandirian (Marsela, 2019). Dalam proses perkembangan ini, remaja juga mengalami masa peralihan dari kanak-kanak menjadi dewasa yang ditunjukkan dari perubahan fisik dan psikis (Farid, 2016, hal. 136). Perkembangan fisik yaitu perubahan tubuh sedangkan perkembangan secara psikis yaitu perubahan mental dan sikap.

Selain perkembangan dan peralihan, remaja juga mengalami dua fase atau dua transisi besar dalam hidupnya yaitu masa remaja awal (usia antara 13-17 tahun) dan masa remaja akhir (usia antara 17-18 tahun). Di masa remaja awal, mereka mulai menunjukkan ketertarikan pada lawan jenis, ingin diperlakukan seperti orang dewasa, kecerdasan semakin berkembang, percaya diri dalam mengungkapkan pendapat dan bependirian teguh, emosi yang meluap-luap, tindakan dan ucapan acapkali tanpa pertimbangan dan bergaya mengikuti sosok orang dewasa yang diidolakannya.

Sedangkan di masa remaja akhir (mendekati masa dewasa), mereka menunjukkan kemantapan dalam menentukan minat, identitas seksual terbentuk, mampu menempatkan diri terhadap kepentingan sendiri dan orang lain. Hal tersebut ditandai dalam perubahan secara psikis maupun fisik (Farid, 2016, hal. 137). Pada masa remaja awal dan 
remaja akhir, setiap remaja memiliki karakter yang berbeda, baik itu karakter yang negatif dan positif. Karakter yang negatif dengan tingkah laku yang mengganggu inilah yang seringkali menjadi perbincangan pada masyarakat di sekelilingnya. Pada masa ini juga terjadi perkembangan dan perubahan yang relatif cepat, baik dalam perubahan fisik, perilaku, kognitif dan emosionalnya. Karena itu tidak mengherankan jika pada masa ini remaja seringkali ingin bebas dari pengawasan orangtua.

Selain itu masa remaja juga kerap kali disebut sebagai masa pemberontakan karena memasuki masa pubertas untuk pertama kali dan berbagai persoalan dalam kehidupan dengan emosi yang tiadk stabil (Karlina, 2020, hal. 5). Ariyanik mengatakan, kenakalan remaja sudah sering terjadi di kalangan masyarakat. Kenakalan remaja merupakan perilaku remaja menyimpang yang bersifat negatif dan yang berdampak buruk pada masyarakat maupun pelakunya (Ariyanik, 2012). Kenakalan remaja merupakan salah satu sikap yang tidak terpuji dan dianggap sebagai suatu masalah sosial yang dapat merusak hubungan di dalam masyarakat. Salah satu kenakalan remaja yang menyimpang adalah tindak pencurian. Tindakan ini seringkali dilakukan hanya untuk membeli rokok dan minuman keras.

Kukuh $(2006,51)$ menyatakan bahwa minuman keras adalah jenis minuman yang mengandung alkohol. Bagi kalangan remaja, minuman keras adalah minuman yang jika dikonsumsi dapat meningkatkan rasa 
kepercayaan diri mereka. Menurut mereka jika mengkonsumsi minuman keras, seorang pemalu akan menjadi seorang pemberani. Mereka juga beranggapan bahwa dengan mengkonsumsi minuman keras dapat menyelesaikan banyak masalah bahkan menambah dan memperbanyak relasi pertemanan. Sedangkan merokok adalah perilaku yang dilakukan berupa membakar tembakau kemudian menghisapnya, yang menimbulkan asap yang dapat terhisap oleh orang-orang disekitarnya (Leavy dalam Nasution, 2007). Sebagian remaja menganggap merokok akan membuat mereka tampak gagah dan yang lain merasakan perasaan tenang dan nyaman ketika mengkonsumsi rokok.

Tetapi kenyataan yang terjadi tidaklah demikian. Minuman keras dan merokok berdampak buruk bagi para penggunanya. Dampak dari mengkonsumsi minuman keras dapat merusak pikiran dan jika berlebihan mengakibatkan seseorang tidak sadarkan diri, sehingga melakukan tindakan yang tidak sesuai dengan kehendaknya. Sedangkan dampak dari merokok dapat mengakibatkan kecanduan. Merokok dapat menimbulkan ketergantungan, menurunkan konsentrasi, menurunkan kebugaran dan mengganggu kesehatan (Wati, 2018, hal. 1).

Kenakalan remaja ini disebabkan karena faktor belum matang dalam berpikir sehingga para remaja masih mudah untuk dipengaruhi dan sering terlibat dalam perbuatan-perbuatan yang negatif. Bagi para remaja, masa ini adalah masa yang penuh dengan masalah, masa yang 
memberikan banyak tekanan, karena para remaja perlu penyesuaian diri dengan perubahan yang terjadi dalam diri mereka dan sekitarnya. (Najmuddin, 2007).

Kenakalan remaja ini bukan hanya mempengaruhi kehidupan sosial masyarakat, namun juga kehidupan dalam lingkungan gereja. Banyak gereja masa kini menghadapi tantangan untuk menyelesaikan persoalan kenakalan remaja ini. Salah satunya diungkapkan oleh Rahmi Pramulia Fitri S dan Yoneta Oktaviani dalam penelitian terhadap Faktor yang Mempengaruhi Perilaku Kenakalan Remaja Pada Siswa-siswi SMA Negeri 2 Model Kota Pekanbaru. Mereka menemukan bahwa kenakalan remaja adalah suatu perbuatan yang dilakukan secara sengaja oleh anak muda yang dapat merusak pribadinya maupun dapat mengganggu kehidupan orang lain dan orang yang berada di sekitarnya. Hal ini terjadi dipengaruhi karena tidak adanya pengontrolan diri dan karena pergaulan bebas (Fitri, 2019).

Kehadiran gereja sangat menolong anggota jemaat untuk menghadapi masalah hidup termasuk masalah kenakalan remaja (Tuhumury, 2019; Patty, 2018; Dauhan, 2013). Dalam Mengatasi kenakalan remaja, Gereja harus berperan aktif dalam dalam mendampingi remaja dalam melewati proses peralihan dan perkembangan dirinya yang seringkali berdampak negatif bagi dirinya sendiri dan masyarakat. 
Beberapa upaya yang dilakukan gereja untuk mengarahkan para remaja Kristen antara lain:

\section{Pendidikan Agama Kristen Bagi Remaja}

Robert I. Browning mengatakan bahwa Pendidikan Agama Kristen bagi remaja merupakan suatu upaya untuk menolong para remaja dalam menemukan kepribadian yang tepat dan menerima tanggung jawab dan nilai yang jelas bagi diri mereka sendiri. Dengan ini maka remaja harus dibentuk dalam pengajaran Kristen atau nilai-nilai Kristen yang berdasarkan pada Alkitab. Sehingga mereka dapat mendengar Injil atau kabar baik/kabar keselamatan, mengalami maknanya, menyadari kasih Allah dalam hidupnya dan meresponnya dalam iman dan kasih (Pasande, 2020, hal. 158-159).

Pada masa remaja peran gereja sangat dibutuhkan bagi remaja melalui bimbingan Pendidikan Agama Kristen agar mereka bisa mengetahui tentang nilai-nilai kekristenan dan tujuan dari Pendidikan Agama Kristen bagi remaja yaitu untuk menjadi remaja yang bertumbuh dalam Iman.

\section{Pelayanan pastoral konseling}

Pelayanan pastoral konseling bagi gereja merupakan cara bagi hamba Tuhan (pelayan) untuk memulihkan orang yang membutuhkan nasihat secara pribadi. 
Untuk itu Gereja dalam hal ini melakukan pelayanan pastoral yang berlandaskan pada pemikiran teologi bagi remaja agar dapat menjawab setiap masalah yang dialaminya, dan Gereja harus memikirkan persoalan dan penyelesaikan untuk mengatasi masalah yang dialami oleh remaja.

\section{Seminar Iman Kristen}

Seminar iman kristen merupakan bentuk pengajaran yang berdasarkan atas nilai-nilai Kekristenan. Seminar ini dibuat oleh Gereja dan ditujukan kepada dua ketegorial, yaitu pemuda dan orang tua. Pertama, seminar iman kristen kepada pemuda, tema-tema yang diseminarkan adalah yang berkaitan dengan kehidupan pemuda seperti dampak dari pergaulan bebas, masalah narkoba dan pacaran menurut nilai-nilai kekristenan dan mengajarkan gaya hidup remaja kristen. Gereja pun harus melakukan kunjungan bagi anak muda yang mengalami masalah dengan mendoakan dan memberikan jalan keluar.

Kedua, seminar iman kristen kepada orang tua. Seminar kepada orang tua mengundang orang tua remaja dengan membahas beberapa topik seperti pemuda dan lingkungan, pentingnya pendidikan orang tua untuk anaknya, dan tanggung jawab orang tua kepada anaknya dalam mendidik (Nurwindayanti, 2019, hal. 272-273). Gereja harus mendidik dan mengajarkan firman Tuhan, karena remaja harus hidup dan dididik berdasarkan nilai-nilai kekristenan yang berlandaskan Alkitab sebagai pedoman hidup. 
4. Komunitas Tumbuh Bersama (KTB)

Komunitas tumbuh bersama (KTB) merupakan sekelompok orang yang menyadari akan kasih karunia Allah dalam hidup ini. Komunitas ini kemudian bertemu untuk belajar firman Tuhan atau pendalaman Alkitab (PA), berbagi pengalaman, saling mendukung dan mendoakan dalam pemulihan karakter yang lebih baik dan bertumbuh sesuai dengan nilainilai kekristenan. Secara teoritis, komunitas tumbuh bersama (KTB) berfungsi sebagai pemuridan yang bertujuan agar anggota kelompok dapat menyadari kasih karunia Allah melalui pendalaman Alkitab, kemudian berbagi pengalaman, memberikan dukungan dan doa. Melalui komunitas tumbuh bersama (KTB) ini, pemuda kristen juga dapat diarahkan untuk terus bertumbuh dengan karakter yang mengarah kepada Kristus (Sitorus, 2020, hal. 203-204).

Dalam upaya membimbing para remaja Kristen, kenakalan remaja tidak dapat dihindari. Berdasarkan hasil wawancara yang dilakukan dengan Bapak Pdt. Adrian monggiapon, Beliau mengatakan bahwa remaja yang berjumlah 9 orang "ada sebagian remaja di GABK Bukit Moria Mangais yang perilakunya tidak baik atau dikategorikan sebagai remaja yang nakal. Beberapa kenakalan remaja di GABK Bukit Moria Mangais, yaitu: 3 orang yang mengkonsumsi minuman keras, 3 orang yang merokok, 1 orang yang mencuri. Dengan demikian menunjukkan bahwa upaya-upaya yang dilakukan Gereja masih terhambat yang 
membuat gereja belum bisa berperan dengan maksimal. Dalam kajian ini ingin melihat kendala apa saja yang dihadapi gereja dalam mengatasi kenakalan remaja yang masih terjadi dalam ruang lingkup jemaatnya khususnya di GABK Bukit Moria Mangais.

\section{METODE PENELITIAN}

Penelitian ini menggunakan metode kualitatif dengan pendekatan studi kasus. Menurut Merriam dan Tisdell (2015), studi kasus adalah deskripsi dan analisis secara mendalam dari bounded system, yakni sebuah sistem yang tidak dapat dilepaskan dari kasus yang satu dengan kasus lainnya (Creswell, 2015)

Data diambil dengan teknik wawancara mendalam. Dengan wawancara mendalam penulis berharap akan mendapatkan data yang komprehensif mengenai tantangan yang dihadapi gereja dalam mengatasi kenakalan remaja. Untuk menjamin reliabilitas data maka penulis menggunakan teknik triangulasi dengan menggunakan tiga kelompok informan. Informan utama adalah pendeta dan majelis jemaat, kelompok kedua adalah orang tua, dan kelompok ketiga adalah pemuda.

Teknik analisis data menggunakan model yang dikemukakan oleh Miles dan Huberman yaitu reduksi data, display data, dan kesimpulan (Sugiyono, 2016). Data berupa jawaban respondon yang telah terkumpul dari wawancara kemudian diuraikan secara objektif dan sistematis menurut relevansi topik dalam penelitian ini. Selanjutnya data tersebut 
akan dianalisa hingga memunculkan kesimpulan dari hasil temuan wawancara yang dilakukan.

\section{HASIL PENELITIAN}

Berdasarkan hasil analisis wawancara dengan para informan ditemukan empat hal yang dianggap sebagai tantangan gereja dalam mengatasi kenakalan remaja di GABK Bukit Moria Mangais.

\section{Kesulitan Berkomunikasi dan Membangun Pendekatan dengan}

\section{Remaja}

Informan pendeta dan majelis jemaat mengatakan bahwa gereja sudah berusaha untuk mengatasi kenakalan remaja tetapi dalam membangun komunikasi dan pendekatan dengan remaja sangatlah sulit. Para remaja tersebut menghindari adanya ajakan untuk menghadiri konseling, ibadah atau penelaahan Alkitab yang diselenggarakan oleh pemuda/remaja. Majelis A menambahkan "Jika kami memberikan nasihat atau masukan dalam tingkah laku para remaja ini, mereka hanya memberikan respon seadanya seolah-olah tidak mendengarkan."

\section{Remaja Kurang Berpartisipasi dalam Kegiatan Gereja}

Informan pendeta dan majelis jemaat mengatakan bahwa remaja kurang berpartisipasi dalam kegiatan ibadah. Hal ini mengakibatkan usaha gereja dalam mengatasi kenakalan remaja menjadi sia-sia. Para remaja tersebut hampir tidak ada yang terlibat dalam kegiatan kerohanian 
yang diselenggarakan. Hal ini dibenarkan oleh informan orang tua yang mengakui bahwa orang tua selalu mendorong anak remajanya untuk aktif dalam kegiatan rohani, tetapi tidak mendapat respon yang baik. Salah satu informan orang tua mengatakan, "Saya selalu mengingatkan anak saya untuk lebih terlibat langsung dalam kegiatan-kegiatan ibadah dengan teman-teman seumurannya, namun dia cenderung menghindar dan lebih memilih keluar bersama teman-temannya yang lain saat jadwal ibadah berlangsung."

\section{Kurang Kerja Sama Antara Gereja dan Orang Tua}

Informan majelis dan pendeta mengatakan bahwa dalam mengatasi kenakalan remaja kurangnya kerja sama antara orang tua dan gereja, sehingga apa yang menjadi usaha gereja tidak berjalan dengan baik. Pendeta mengungkapkan "Ada kalanya orang tua beberapa anak tidak menunjukkan sikap tegas terhadap kebiasaan kurang baik anak-anak mereka. Kami dari gereja kesulitan untuk ikut terlibat langsung jika para orang tua saja tidak mengambil sikap."

Namun demikian, informan orang tua mengatakan bahwa mereka sudah berusaha menasihati anak namun cukup sulit. Orang tua B mengatakan, "Dalam menasihati anak kami, selaku orang tua kami sudah melakukan yang terbaik. Namun, kesadaran dari anaknya sendiri tidak ada." 
Tidak Adanya Penggerak Kurangnya dalam Gereja untuk Mengatasi Kenakalan Remaja

Informan pemuda yang terlibat dalam pelayanan gereja menilai bahwa dalam mengatasi kenakalan remaja gereja kurang memiliki kemampuan. Gereja sudah menyediakan berbagai sarana untuk merangkul para remaja, tetapi tampaknya tidak tepat sasaran, karena terbukti bahwa para remaja tersebut tetap saja menutup diri. Orang tua pun seperti kewalahan menghadapi anak-anak remaja.

Salah satu informan mengatakan "Gereja telah menyediakan sarana-sarana untuk merangkul para remaja Kristen namun kenyataannya, bagi anak yang bermasalah kurang tepat sasaran karena dari diri mereka sendiri pun tidak mau membuka diri. Upaya dari gereja pun akan percuma."

\section{Usulan agar gereja bisa mengatasi kenakalan remaja}

Selanjutnya peneliti meminta informan untuk memberikan usulan kepada Gereja sebagai upaya untuk mengatasi kenakalan remaja. Ada tiga usulan yang dirangkum sebagai berikut. Pertama, Informan mengatakan bahwa Gereja harus membangun hubungan atau pendekatan yang baik dengan remaja yang tergolong dalam masalah kenakalan remaja. Kedua, pelayan Gereja harus mengadakan dialog dan diskusi dengan orang tua tentang cara mengatasi kenakalan remaja. Ketiga, Gereja harus mengadakan bimbingan dan pelayanan khusus bagi remaja 
sebagai upaya untuk menghadapi masalah-masalah remaja yang terjadi dan akan terjadi di masa yang akan datang. 


\section{PEMBAHASAN}

Berdasarkan hasil penelitian di atas ada tiga hal yang menarik untuk dibahas:

\section{Pertama, gereja sulit berkomunikasi dengan remaja}

Komunikasi merupakan suatu tindakan yang dilakukan oleh satu orang atau lebih dengan cara mengirim dan menerima pesan, serta aktivitas menyampaikan apa yang ada dipikiran dan disampaikan kepada orang lain (Oktavia, 2016). Dalam menjalin komunikasi terkadang terjadi hambatan atau kendala, hal ini pula yang dialami oleh Gereja. Kendala yang terjadi di Gereja yaitu kesulitan untuk membangun komunikasi dengan remaja. Kesulitan ini menurut Sari dikarenakan pesan yang disampaikan terlalu panjang sehingga membuat anak remaja cepat merasa bosan (Sari, 2017). Kendala ini dialami oleh para pelayan Tuhan yang ada di GABK Bukit Moria Mangais karena usia mereka sudah relatif tua, sehingga remaja kurang nyaman untuk menceritakan apa yang mereka alami, mereka juga merasa cepat bosan jika berkomunikasi dengan para pelayan Tuhan ini. Para remaja lebih menyukai menjalin komunikasi dengan teman sebayanya, menurut mereka teman sebaya lebih mudah untuk diajak berbagi cerita, tempat paling nyaman untuk mencurahkan segala isi hati serta pengalaman yang mereka sedang mereka alami. Inilah yang menjadi kendala dari segi komunikasi antara para pelayan Tuhan dan remaja di GABK Bukit Moria Mangais. 
Jurnal Misioner

p-ISSN: 2776-494X ; e-ISSN: 2776-4958

www.jurnal.sttkibaid.ac.id//Vol. 1 No. 2 (2021), hal. 206 - 226

(C) 2021 Pira Satria Sitoki, Junni Yokiman, Nanchy Lepong Bulan 


\section{Kedua, remaja tidak berpartisipasi dalam kegiatan gereja}

Partisipasi dan keikutsertaan para remaja dalam setiap kegiatan yang diadakan memiliki pengaruh yang sangat besar dan penting bagi mereka, khususnya kegiatan kerohanian. Menurut Huneryear dan Heoman partisipasi adalah keterlibatan mental dan emosional dalam situasi kelompok yang mendorong untuk memberi sumbangan terhadap tujuan kelompok serta berbagi tanggung jawab bersama (Setya, 2012, hal. 14). Namun yang terjadi pada remaja di GABK Bukit Moria Mangais tidak demikian. Mereka kurang berpartisipasi dalam kegiatan yang diadakan oleh Gereja. Hal ini menunjukkan bahwa remaja di GABK Bukit Moria Mangais masih kurang memberikan sumbangsih kepada Gereja, sehingga mereka tidak memiliki beban dan tanggung jawab untuk dapat membantu dan berpartisipasi dalam pencapaian tujuan pelayanan yang ada di Gereja tersebut. Menurut Christian Fredy Naadi hal ini bisa terjadi karena sistem pelayanan di dalam Gereja tidak menarik (Naa, 2017). Sistem pelayan yang tidak menarik Inilah yang menjadi penyebab mengapa remaja di GABK Bukit Moria Mangais kurang berpartisipasi dalam program dan kegiatan yang diadakan oleh Gereja. sehingga program atau kegiatan yang diadakan oleh Gereja untuk remaja kurang membuahkan hasil. 


\section{Ketiga, tidak adanya penggerak dalam mengatasi kenakalan remaja}

Dalam mengatasi suatu masalah di dalamnya dibutuhkan penggerak. Kamus Besar Bahasa Indonesia mengartikan penggerak sebagai orang yang menggerakan. Penggerak yang dimaksud di sini adalah orang tua atau Gereja. Orang tua atau keluarga adalah tempat bertumbuh bagi anak mulai bayi sampai dewasa untuk dididik dan diarahkan agar dapat berkembang dengan baik (Novita, 2016). Sedangkan Gereja merupakan tempat yang penting di mana remaja dibina atau dibimbing dalam kerohanian mereka (Sriyanto, 2020). Orang tua sebagai tempat bertumbuh yang memiliki peran membimbing dan mengarahkan remaja agar berkembang dengan baik, sedangkan Gereja sebagai tempat bagi remaja untuk dibina dan dibimbing harus menjalin dan membangun kerjasama yang baik, khususnya dalam menangani masalah kenakalan remaja. Haryono mengungkapkan kerja sama adalah usaha bersama antara dua pihak atau lebih yang saling berinteraksi atau menjalin hubungan yang bersifat dinamis untuk mencapai suatu tujuan bersama (Ariyanto, 2019).

Inilah mengapa Gereja dan orangtua harus menjalin dan membangun kerjasama yang baik, sehingga tujuan Gereja dan orang tua dapat tercapai. Kerjasama ini harus dilakukan secara terpadu dan yang diarahkan untuk tujuan mengatasi kenakalan remaja yang terjadi di GABK Bukit Moria Mangais. Namun, hal ini belum dilakukan sebab belum pihak 
atau penggerak baik dari pihak Gereja maupun orang tua untuk mengupayakan kerjasama ini dapat terjalin. oleh karena itu dibutuhkan kesadaran dari pihak Gereja maupun orangtua untuk menjalin kerjasama ini sesegera mungkin, agar kenakalan remaja dapat segera diatasi dan tujuan Gereja sebagai pembimbing dan pembina kerohanian remaja dapat tercapai.

\section{KESIMPULAN}

Dari uraian hasil pembahasan di atas dapat disimpulkan bahwa tantangan Gereja dalam mengatasi kenakalan remaja di GABK Bukit Moria Mangais antara lain disebabkan oleh kesulitan Gereja untuk menjalin komunikasi dengan remaja, kurangnya berpartisipasi remaja dalam program atau kegiatan yang diadakan Gereja karena program dan kegiatan yang diadakan kurang menarik bagi remaja, dan tidak adanya penggerak yang menggerakkan kerjasama antara Gereja dan orangtua untuk mengatasi masalah kenakalan remaja. Gereja, orang tua dan remaja harus menjalin kerjasama yang baik untuk dapat mengatasi masalah kenakalan remaja ini, sehingga tujuan Gereja, orang tua dan remaja itu sendiri dapat tercapai.

\section{DAFTAR PUSTAKA}

Ariyanik, S \& Elly, S. (2012). Fenomena Kenakalan Remaja di Desa Wonorejo Kabupaten Situbondo. Entitas Sosiologi , 1, 4.

Creswell, J. W. (2015). Penelitian Kualitatif \& Desain Risetl. Yogyakarta: Pustaka Pelajar. 
Dauhan, B. A. (2013). Gereja dan Permasalahn Remaja (Pelayanan Gereja Terhadap Permasalahan Remaja di GKJ Bandungan Dalam Konteks Lingkungan Wisata Hiburan Malam. Program Studi Teologi FTEO-UKSW.

Ariyanto, N., Wibowo. (2019). Modul KKN Tematik Desa Membangun Kerja Sama Desa. Jakarta: Transmigrasi Republik Indonesia.

Farid, M. (2016). Konsep Diri, Adversity Quotient dan Penyesuaian Diri pada Remaja. Psikologi Indonesia , 5, 137.

Fitri, R. P., \& Oktaviani, Y. (2019). Faktor yang Mempengaruhi Perilaku Kenakalan Remaja pada Siswa-Siswi MAN 2 Model Kota Pekanbaru. Midwifery Science , 3, 5.

Gainau, M. S. (2016). Pendidikan Agama Kristen (PAK) Remaja. Jl. Cempaka: PT. Kanisius.

Karlina, L. (2020). Fenomena Terjadinya Kenakalan Remaja. Edukasi Nonformal. 5.

Kukuh. (2006). Generasi Gaul Tanpa Drugs dan Alkohol. Jakarta: Kaysa Media.

Levy, M.R. (1984). Life and Health. New York: Random House.

Marsela, R.M., \& Supriatna, M. (2019). Konsep Diri: Definisi dan Faktor. Innovative Counseling: Theory, Practice \& Research , 2, 3.

Maycoryani \& Tuhumury, B. Z. (2019). Kajian Peran Gereja Untuk Mengatasi Kenakalan Remaja Di GKII Long Peso Kalimantan Utara. Repository Skripsi Online, 1(2), 123-128. Retrieved from ahttps://skripsi.sttjaffray.ac.id/index.php/skripsi/article/view/34

Merriam, S. B., \& Tisdel, E. J. (2015). Qualitative Research: A Guide To Design And Implementation. Fourth edition. San Fransisco: JosseyBass.

Mulyatiningsih, R. (2004). Bimbingan Pribadi-Sosial, Belajar dan Karier. Petunjuk Praktis Diri Sendiri Untuk Siswa SMP dan SMU. Jakarta: PT. Gramedia Widiasarana Indonesia.

Naa, C.F. (2017). Konten Versus Sistem di Pelayanan Pemuda GKI. Dikutip dari https://selisip.com/2017/05/konten-versus-sistem-dipelayanan-pemuda-gki/

Najmuddin, H. (2007). Memahami dan Membimbing Remaja Nakal. Kuala Lumpur: PTS Professional Publishing.

Nasution, I. K. (2007). Perilaku Merokok Pada Remaja. Medan: Fakultas 
Kedokteran Universitas Sumatra Utara.

Novita, D., Amirullah, Ruslan. (2016). Peran Orang Tua Dalam Meningkatkan Perkembangan Anak Usia Dini di Desa Air Pinang Kecamatan Simeulue Timur. IImu Mahasiswa Pendidikan Kewarganegaraan Unsyiah , 1, 241.

Nurwindayanti. (2019). Penuntun Pengaruh Saat Teduh dan IBadah Terhadap Pengambilan Keputusan Dalam Pengambilan Pasangan Hidup. FIDEI , 2, 272-273.

Oktavia, F. (2016). Upaya Komunikasi Interpersonal Kepala Desa Dalam Memediasi Kepentingan PT. Bukit Borneo Sejahtera Dengan Masyarakat Desa Long Lunuk. Ilmu Komunikasi , 4, 241.

Pasande, P., Asa, F.O., \& Tulaka, E. E. (2020). Substansi Pendidikan Agama Kristen Bagi Anak dan Remaja. Luwuk Banggai: Pustaka Star's Lub.

Patty, S., \& Sampe, D. P. Relasi Kontrol Diri Dengan Perilaku Agresif Pada Remaja Laki-Laki Peminum Keras Kontekstual Pada Remaja Di Jemaat GPM Imanuel OSM-Ambon. Institutio: Jurnal Pendidikan Agama Kristen Vol. IV No. II.

Sari, A. (2017). Komunikasi AntarPribadi. Yogyakarta: CV Budi Utama.

Setya, R., Putri. (2012). Partisipasi Masyarakat Dalam Proses Kebijakan Mutu Sekolah di SD Kanisius Kadirojo Kalasan. S1 Thesis, Universitas Negeri Yogyakarta , 14.

Sitorus, T. T. (2020). Implikasi Pembinaan Pemuda Gereja atas Faktorfaktor Penyebab Kasus Hamil di luar Nlkah. Teologi Injili dan Pembinaan Warga Jemaat , 4, 203-204.

Sriyanto, B., Sihite, T. S. H. (2020). Peran Gereja Dalam Pembinaan Kerohanian Remaja di Gereja Pantekosta di Indonesia Kota Palangkaraya. Teologi Pantekosta , 2, 103.

Sugiyono. (2016). Metode Penelitian Kuantitatif, Kualitatif dan R\&D. Bandung: Alfabeta.

Wahyuni, S. (2021). Psikologi Remaja Penanggulangan Kenakalan Remaja. Luwuk Banggai: Pustaka Star's Lub.

Wati, S. H., Bahtiar, Anggraini, D. (2018). Dampak Merokok Terhadap Kehidupan Sosial Remaja. Neo Societal , 3, 1.

Yin. (2013). Studi Kasus Desain dan Metode. Jakarta: PT. Raja Grafindo. 